\title{
Pentek Concrete Scabbling System: Baseline Report; Summary
}

\section{Topical Report July 31, 1997}

RECEIVED CED 24998 OSTI

Work Performed Under Contract No.: DE-FC21-95MC32260

For

U.S. Department of Energy

Office of Environmental Management Office of Technology Development 1000 Independence Avenue Washington, DC 20585
U.S. Department of Energy

Office of Fossil Energy

Federal Energy Technology Center

Morgantown Site

P.O. Box 880

Morgantown, West Virginia 26507-0880

DSTREUTAN OF THIS DOCUMENT IS UNAMATED
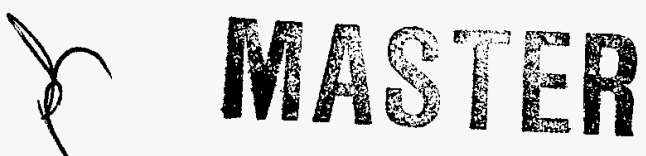

DTC QUALTF IFPEEUTHD \&

By

Operating Engineers National Hazmat Program

250 Airport Circle

Beaver, West Virginia 25813 


\section{Disclaimer}

This report was prepared as an account of work sponsored by an agency of the United States Government. Neither the United States Government nor any agency thereof, nor any of their employees, makes any warranty, express or implied, or assumes any legal liability or responsibility for the accuracy, completeness, or usefulness of any information, apparatus, product, or process disclosed, or represents that its use would not infringe privately owned rights. Reference herein to any specific commercial product, process, or service by trade name, trademark, manufacturer, or otherwise does not necessarily constitute or imply its endorsement, recommendation, or favoring by the United States Government or any agency thereof. The views and opinions of authors expressed herein do not necessarily state or reflect those of the United States Government or any agency thereof. 


\section{PENTEK CONCRETE SCABBLING SYSTEM HUMAN FACTORS ASSESSMENT - BASELINE}

\section{SECTION 1 - SUMMARY}

\section{Technology Description}

The Pentek concrete scabbling system consists of the MOOSE ${ }^{\circledR}$ scabbler, the SQUIRREL ${ }^{\circledR}-1$ and SOUIRREL ${ }^{\circledR}-$ III scabblers, and VAC-PAC ${ }^{\circledast}$. The scabblers are designed to scarify concrete floors and slabs using cross section, tungsten carbide tipped bits. The bits are designed to remove concrete in $3 / 8$ inch increments. The bits are either 9tooth or demolition type. The scabblers are used with a vacuum system designed to collect and filter the concrete dust and contamination that is removed from the surface.

\section{Key Results}

The human factors assessments focused on two main areas of exposure: dust and noise. The dust exposure was found to be minimal, but noise exposure was significant. Further testing for each of these exposures is recommended because the outdoor environment where the testing demonstration took place may skew the results. It is feasible that the dust and noise levels will be higher in an enclosed operating environment. In addition, other areas of concern were arm-hand vibration, whole-body vibration, ergonomics, heat stress, tripping hazards, electrical hazards, machine guarding, and lockout/tagout.

\section{SECTION 2 - HEALTH AND SAFETY EVALUATION}

\section{General Safety and Health Concerns}

Safety and health issues of concern with the Pentek concrete scabbling technology included tripping hazards, electrical hazards, rotating machinery, lockout/tagout, heat stress, ergonomics, arm-hand vibration, whole-body vibration, noise, dust, and communication.

\section{Industrial Hygiene Monitoring}

During the testing demonstration, sampling was conducted for dust and noise. In addition, the wet-bulb globe temperature was monitored and observational evaluation was conducted for ergonomics and armhand vibration and whole-body vibration.

Ergonomically there is potential for muscle/back and knee stress and/or injury. Arm-hand vibration was not quantitatively measured, but it was readily apparent that there was exposure to arm-hand vibration that could potentially cause problems such as Raynaud's syndrome. There was also exposure to whole-body vibration.

Heat stress was monitored using wet-bulb globe measurements and worker physiological measurements such as blood pressure, pulse, and temperature. Work/rest regimen recommendations were made in accordance with $A C G I H$ recommendations.

Personal sampling for total dust was conducted on the equipment operators. Personal sampling results were below allowable levels. Noise monitoring recorded a dose of $164 \%$ or an 8-hour TWA of 93.5 $\mathrm{dBa}$ for operator number 1 and $174.75 \%$ or an 8-hour TWA of $94 \mathrm{dBa}$. This exceeds the OSHA action level of $85 \mathrm{dBa}$ and the permissible exposure of $90 \mathrm{dBa}$. A hearing conservation program will be essential for 
anyorie working with or around this equipment.

\section{SECTION 4 - REGULATORY/POLICY ISSUES}

\section{Human Factors Interface}

The technology was evaluated for operator interface with Anti-C PPE including a full face air-purifying respirator. While wearing the PPE, operators experienced some visibility problems due to the full face respirator, and some loss of tactile sensation and dexterity during maintenance activities. In addition, there was an increase in heat stress associated with the protective ensemble.

\section{SECTION 3 - TECHNOLOGY APPLICABILITY}

On observation, the technology did deposit some visible dust into the atmosphere. Air monitoring did not evidence an excessive dust level; however, the windy outdoor testing environment was not representative of an indoor work environment. There was some larger debris left on the surface at the sides of the scabbling head.

The MOOSE ${ }^{\oplus}$, SOUIRREL ${ }^{\circledR}-1$, and SOUIRREL ${ }^{\circledR}$ III will need to be torn down to decontaminate. This will not necessarily guarantee that decontamination for alpha will be complete. It will be difficult to survey for alpha contamination due to all of the small spaces in the equipment that are hard to reach with a probe. According to the technology representative, many parts, such as the hoses and brushes, may be considered consumables.
The site safety and health personnel where the Pentek scabbling technology is being used need to be concerned with safety and health regulations applicable to the issues discussed above. Regulations that will apply may include but not be limited to the following areas: housekeeping, electrical, hand and power tools, machine guarding. lockout/tagout, ionizing radiation, toxic and hazardous substances, noise, respiratory protection, PPE, HAZCOM, HAZWOPER, and arm-hand and whole-body vibration.

\section{SECTION 5 - OPERATIONAL CONSIDERATIONS \& RECOMMENDATIONS}

Recommendations for improved worker safety and health include good housekeeping, ergonomic training and awareness, a clamping system for vacuum hoses, assessing the SQUIRREL ${ }^{\circledast}$ for possible operation from a standing position, guarding all moving parts, assuring proper vacuum adjustment for adequate air flow, and engineering, administrative, and/or hearing protection be used for compliance with the OSHA noise standard.

Due to the windy outdoor testing conditions, it is recommended that the noise and dust monitoring be conducted while the technology is in use in an enclosed environment. Since Level A or Level B PPE may be required for contaminants other than alpha radiation, it is recommended that the human factors interface for these levels of protection be conducted.

Research supported by the U.S. Department of Energy's Federal Energy Technology Center, under cooperative agreement DE-FC21-95MC32260 with the Operating Engineers National HAZMAT Program, 250 Airport Circle, Beaver, W 25813, phone 304-253-8674, fax 304-253-7758. This report was prepared with the support of the US DOE; however, any opinions, findings, conclusions, or recommendations expressed herein are those of the author(s) and do not necessarily reflect the views of the DOE. 
M98002050

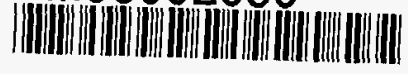

Report Number (14) $\Delta O \varepsilon / m c / 32260--5845$

Jubl. Date (11) 19970731

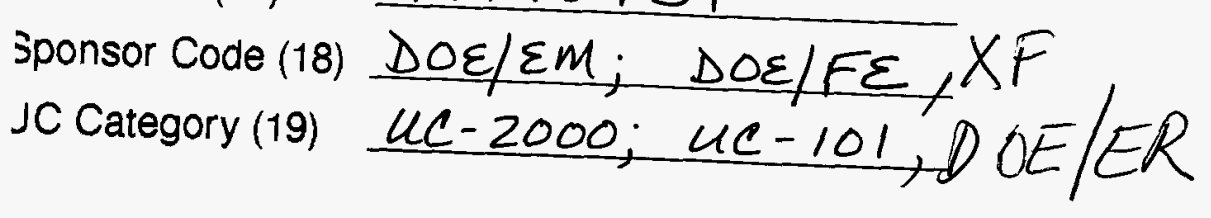

$D O E$ 